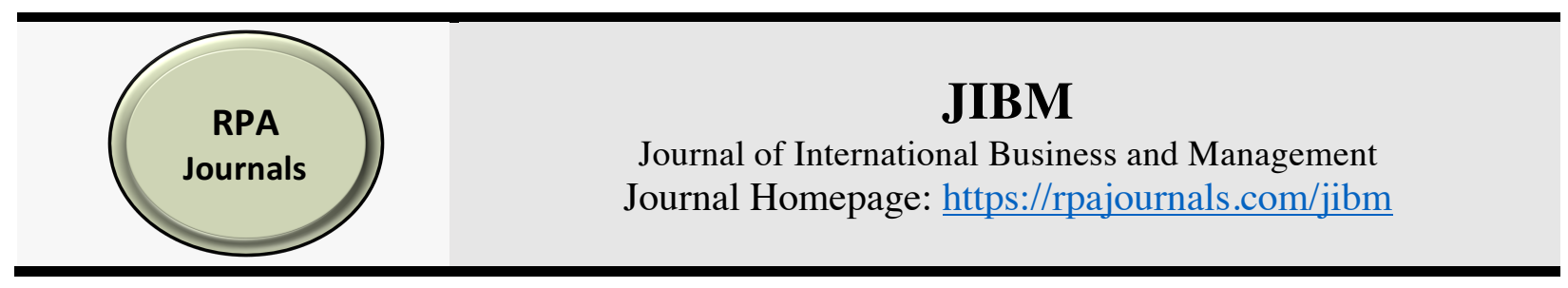

\title{
Leadership Behaviour Influence Organisational Commitment, Organisational Culture and Job Satisfaction at Public University in Malaysia
}

\author{
Muhammad Rozien Zakwan Bin Ab Rahman" \\ Amer Hamzah Bin Jantan ${ }^{2}$ \\ School of Business and Economics \\ University Putra Malaysia (UPM), Malaysia ${ }^{\star 22}$
}

\begin{abstract}
Additional and more firms nowadays face adaptive challenges: changes in societies, markets, and technology around the globe are forcing them to clarify their values, develop new ways, and learn new ways that of operative. Therefore, the most significant task for leaders within the face of such challenges is mobilizing individuals throughout the organization to try and do adaptive work. Leadership plays an important role in verifying the amount of organisational commitment, organisational culture and job satisfaction in a corporation. The results obtained through this study will assist high management in creating sophisticated and strategic choices concerning future employment practices and trends.
\end{abstract}

Keywords: Leadership Behavior, organisational Commitment, organisational Culture, Job Satisfaction, Public University Malaysia

\footnotetext{
*Corresponding author: Muhammad Rozien Zakwan Bin Ab Rahman Email: zakwan_rahman@yahoo.com
}

DOI: https://doi.org/10.37227/jibm-2019-04-71

\section{Introduction}

Leadership is a vital performance of management that helps to maximise potency and to attain organisational goals. The word leadership has been represented in terms of the position, temperament, responsibility, influence process: instrument to attain a goal, behaviors (Limsila \& Ogunlana, 2008). Mostly, leadership is possessed by individuals within the high of a hierarchy. During this journal, leadership are mentioned because of the board of director or manager in a corporation. Leadership is loosely outlined because the relationship between a private and a bunch engineered around some common interest whereby the group behaves in an exceeding manner directed or determined by the leader (Shastri, Shashi Mishra \& Sinha, 2010).

Kotter (2008), in his article titled 'What Leaders very Do,' explained the variations between leadership and management. He expressed that management is regarding handling quality meantime leadership is coping with an amendment. This might be terminated that leadership can ought to be visionary and continuously reply to the external encompassing. A frontrunner with smart leadership talent can set the direction of the organization in gaining 
the monetary edges et al. Besides that, leadership will give talent to orientating and motivating individuals (Kotter, 2008). These 3 skills, setting a direction, orientating and motivation, are the apparent reason to differentiate managing and leadership.

An employee can play an important role in a corporation. The worker can carry the task given by the leader and completed the whole mission to reach the fascinating objective. organisational commitment is usually represented because the key considers the link between staff and organizations (Raju \& Srivastava, 1994). staff will have an honest and positive relationship with the organization. With an honest organisational commitment, organisational culture and job satisfaction, the worker and organization can work towards one objective.

However, inbound cases, an honest leader won't continuously succeed. An honest leader, while not a good follower can flank sort of a ship without a crew. Whether or not the followers will follow the ideology of the leader can replicate in their organisational commitment. Afoul organisational commitment can affect the organization internally. This might be thought about as an outbreak. Initiate as someone or tiny team can evolve to an outsized quantity of individuals that eventually transfer down the corporation. For example, Walmart's staff protest the new direction of their leadership and moving these pictures of Walmart (Stracthan, 2013).

Consistent with Kavanagh and Ashkanasy (2006), several amendment efforts fail as a result of the importance of people and the cognitive-affective nature of organisational changes is underestimated by organizational leaders. Brewage and Nohria (2000) conjointly aforementioned that a lot of amendment initiatives fail. This is often a result of several leadership designs been applied by the leader who fails to replicate the requirements from the worker. The leader fails to clarify their leadership vogue and dictates that workers ought to abide by the new direction. A leader's stress on collective identity was associated with worker level of identification with the leader (Shamir et al., 1998).

Wallach (1983) have highlighted analysis variations results between a relationship with the result or work attitudes like satisfaction and organisational commitment. It explains several previous empirical phenomena as Widyarini (2009), that states that verify and innovation culture encompasses a positive impact on job satisfaction. Silverthone (2004) states associate innovative and verify culture creates the next level of satisfaction than officialdom culture. Encouraging a verify culture makes higher organisational commitment than innovative culture and even forms culture. Mathieu and Zajac (1990) expressed that organisational culture doesn't become one antecedent of organizational commitment. What is more, O'Reily, Chatman and Cadwell (1991) and Lahiry (1994) states that culture that, according to strategy, will increase organisational employee's commitment to the company. However, Lahiry (1994) conjointly highlights the weak relationship between organization culture and commitment.

The most objective of this analysis is to produce empirical proof concerning the leadership behavior which will influence the organisational commitment, job satisfaction and organisational culture. Whereas a relationship between leadership and emotional, organisational commitment has been through empirical observation established (e.g. Castro, Perinan \& Bueno, 2008; Felfe, Yan \& Six, 2008; Metscher, 2005; Walumbwa et al., 2005, 2004; Dvir, Kass \& Shamir, 2004; Bono \& decide, 2003; Meyer et al., 2002; W.A. Lowe, 2000; Bycio et al., 1995). during this paper, the first queries are asked are: 1) Is leadership behavior can influence the organisational commitment? 2) Is leadership behavior will influence task satisfaction? 3) Is leadership behavior will influence the organizational culture? 


\section{Leadership Behaviour}

\section{Literature Review}

Leadership is all regarding the follow of picturing, facultative and energizing the staff (Rad, 2006). consistent with Maqsood et al. (2013), leadership may be a procedure to influence individuals to attain the specified result. Therefore, leadership may be a methodology been applied by the manager to attain the organization's goals and objectives. While not a correct leadership talent, the worker won't understand the precise work. Leadership involves the abilities to come up with, organizing, dominant and leading. The manager can understand all the main points and directions in finishing the work. Leadership, in an exceedingly new method that creates a replacement vision, increases the self-worth of staff through coordination and communication (Bohn \& Grafton, 2002).

There are different types of leadership starting from autocratic, attractive, participative, situational, officialdom, democratic, individualistic, transactional and transformational leadership (Mosadghrad, 2004). during this paper, autocratic, officialdom and democratic are wont to live the leadership talent. The transformational and transactional leadership vogue has continuously been used because of the predictor of leadership style. Each leader should fathom the various designs for the different things and maybe acquainted with a time of demonstration of a selected vogue ( $\operatorname{Rad} \&$ Yarmohammadian, 2006). Kreitner (1995) expressed that leadership behavior is wont to create a big impact on staff to boost organization performance. An honest manager can understand to use leadership vogue in managing their work towards a hit.in the bound study; it's urged that leadership vogue supported organization's culture ( $\operatorname{Rad}, 2006)$.

Currently, the foremost prestigious contingency approach to leadership is that the Path-Goal theory (Robbins, 2005). This theory states that the most goal of the leader is to assist subordinates in attaining the subordinates' goals effectively, and in producing them with the mandatory direction and support to attain their own goals yet as those of the organization (Silverthorne, 2001). during this theory, the leader will increase follower motivation by either (1) elucidative the follower's path to the rewards that are out there, or (2) increasing the rewards that the follower values and wishes. Directive leadership tells subordinates specifically what they're presupposed to do. Mehta et al. (2003) intercalary that this leadership vogue provides specific direction to subordinate work activity by organizing and shaping the task atmosphere, distribution the mandatory functions to be performed, specifying rules, rules and procedure to be followed in accomplishing tasks, elucidative expectations, programing work to be done, establishing communication networks and evaluating work cluster performance.

Directive leadership behaviour is just like the initiating organisational or taskoriented leadership vogue represented earlier. Mehta et al. (2003), more careful that a verify leadership vogue is one during which the leader creates a helpful task atmosphere of psychological support, mutual trust and respect, helpfulness and friendliness. Participative leadership consults with subordinates regarding choices. Leader behaviour includes posing for opinions and suggestions, encouraging participation in the higher cognitive process, meeting, discussion and written suggestions.

\section{Organizational Commitment}

Organization's success is predicated on employee's commitment and their focus towards achieving the organization's prime goals (Khan er al, 2012). The organization couldn't afford to lose their worker, particularly the proficient worker. organizational commitment is of nice 
importance, particularly in an exceedingly time of economic and monetary crisis. This is often as a result of someone WHO is committed is additionally driven to figure and adapt more simply to any new plan or amendment that the organization goes through (Cooper \& Cooper, 2003; Gennard \& decide, 2005). organisational commitment can increase the commitment of purchasers, and this results in a far better complete image and name. Once the organization has committed staff, this conjointly results in a lower rate of turnover as a result of the individuals feel a sense of happiness to the corporation and don't wish to depart (Ulrich \& Smallwood, 2003; Sims, 2003).

Allen and Meyer (1990) classified organisational commitment into 3 components: emotional, continuance and normative commitment:

1. Emotional Commitment: Refers to the employee's emotional attachment to, identification with, and involvement in the organization.

2. Continuance Commitment: Refers to commitment supported the prices that the worker associated with the departure of the organization.

3. Normative Commitment: Refers to the employee's feeling of obligation to stay with the organization.

Staff with a high level of organizational commitment have important contributions to the action of the organization beneath competitive conditions (Feldman \& Moore, 1982). The commitment of staff to the organization and victimization all their skills and experience for the advancement of the organization involved may be an important issue. The institution might have a preference to figure with those high levels of organizational commitment. The explanation for this is often the assumption that challenges encountered on the thanks to reaching goals are also overcome with such staff. Attributes of staff in terms of organizational commitment is the key guide for the success of a business. Consistent with Porter et al. (1974) associated with Mowday et al. (1982) the degree of organisational and social control collaboration a worker feels, their participation in the higher cognitive process, the leadership vogue associated organizational culture influence whether or not a worker has high or low organizational commitment.

\section{Job Satisfaction}

Robbins (2005) outlined job satisfaction as a group of feelings that a private hold towards his or her job. This relies on what number of them would like, and desires are happy (Finn, 2001). Job satisfaction is understood as a construct with multi aspects that has the worker feelings regarding totally different job parts, intrinsic yet as alien. It includes specific options of satisfaction related to pay, benefits, direction, organizational practices, promotion, work conditions and relationships with co-workers (Misener et al., 1996). There are some options of leadership having a positive relationship with job satisfaction like social relations, serving to behavior among members of the team, the extent of collaborating in the higher cognitive process, compensation satisfaction and appraisal system (Cohen \& Austion, 1993; Hallberg, 2006; Gleason, 1995).

In a corporation, what makes associate worker leave or shall leave continuously becomes a large question for any company (Mahdi et al. 2012). many studies have examined job satisfaction as an associate antecedent of turnover intentions. (for instance, Mobey et al, 1979; value \& Mueller, 1981; Shore \& Martin, 19889; dramatist, 1997; Ghiselli et al, 2001; Mcbey \& Karakowsky, 2001). Employment that entails high pay, high security, bigger promotional opportunities, attention-grabbing work and truthful and friendly direction, all of that is judged as the way to attain work and non-work goals, ought to cause a positive feeling of prosperity (Mahdi et al., 2012). 
Job satisfaction is one of the factors that contribute to people's intention to quit their jobs (Moore, 2002). A relevant by Spector (1997) and Hirschfeld (2000) indicate that the various aspects of job satisfaction can be split consistent with Herzberg's 2 dimensions. The intrinsic satisfaction refers to job task and job content like selection, autonomy, talent utilization, self-fulfilment and self-growth. And at the identical time, Buitendach and Witte (2005) take in that alien motivation refers to alternative factors like pays, co-workers and work conditions.

Many factors influence job satisfaction. Worrell (2004) divided these factors into 3 teams, that are demographic information, age, gender and race, intrinsic factors, action, recognition, work itself, responsibility, advancement and growth alien factors, company policy, direction, relationship with the boss, work conditions, relationship with peers and wage.

\section{Organisational Culture}

Schein (2010) outlined organizational culture as a group of basic understood assumptions regarding however the planet is and should to be, that a bunch of individuals share, which determines their perceptions, thoughts, feelings and to a point their over behaviour. Organizational culture is the mental attitude of individuals that distinguishes them from one another, inside the organization or outside the organization (Hofstede, 1991). This includes values, beliefs and behaviors of the employees different from the opposite organization. Agnew and Van Balkom (2009) known organizational culture as a key indicator of the undefeated organizational amendment, noting that institutional leaders meaning to produce and implement effective group action ways ought to perceive their institution's organizational culture. This means organizational culture is part that represents the organization.

The study on organizational culture will combat a large number of aspects. Robbins (2005) careful that there are seven primary characteristics that, in the mixture, capture the essence of associate organization's culture: innovation and risk-taking, attention to detail, outcome orientation, individuals' orientation, team orientation, aggressiveness and stability. Every one of those characteristics will exist on a time from low to high. Robbins (2005) what is more explained that the organizational culture is pictured as an associate intervening variable; staff type an overall subjective perception of the organization supported these seven factors, and these perceptions, favourable or otherwise, affect worker performance and satisfaction, with the impact being bigger for stronger cultures.

Daft (2005) mentioned on the 3 levels of company culture, with every level changing into less obvious, i.e. visible, expressed values and underlying assumptions and deep beliefs. Its strength may determine culture, that is that the degree of agreement among staff regarding the importance of specific values and ways that of doing things, a strong culture is one that core values are each intensely control and widely shared, and thence have a bigger impact on worker behavior. Analysis has found that a powerful culture is joined to a high agreement among members, will increase behavioural consistency, builds cohesiveness, loyalty and organizational commitment and additional significantly, reduces turnover (Robbins, 2005). 


\section{Theoretical Framework}

The theoretical framework is shown in Figure one.1. The leadership behavior is considered as a variable quantity. Meanwhile, the organizational commitment, organizational culture and job satisfaction are thought about as dependent variables.

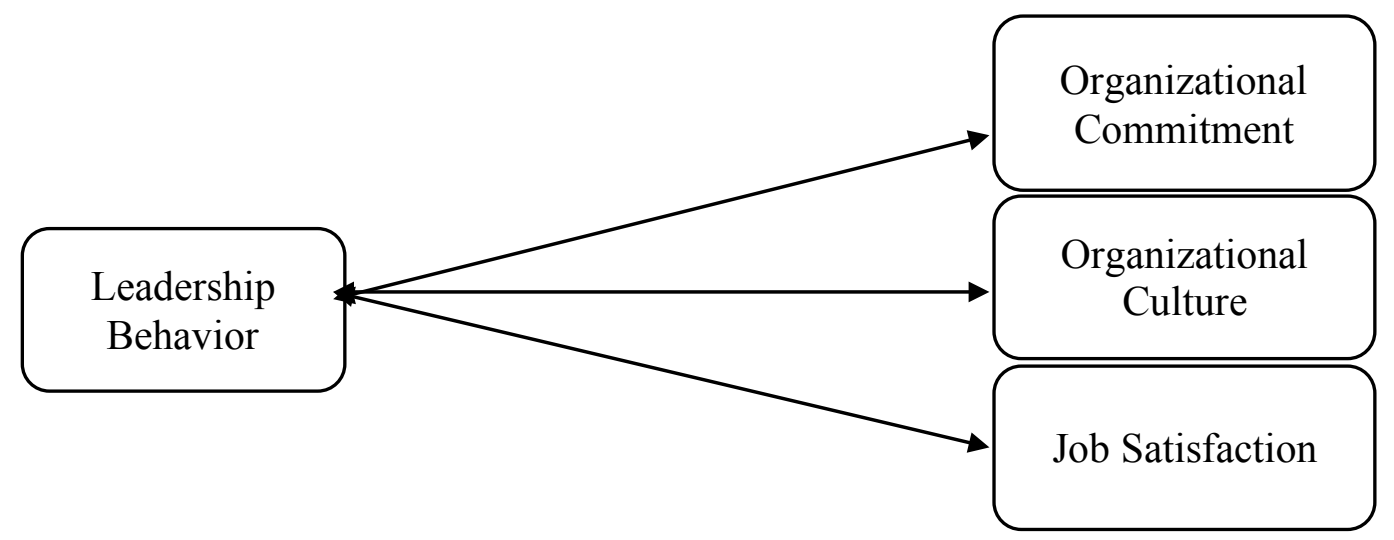

Figure 1: Research Framework

\section{Hypotheses}

For this analysis, few hypotheses been drawn dead set notice the link between every variable. The most objective of this analysis is to search out the link between leadership behavior and organizational commitment, organization culture and job satisfaction.

Hypothesis 1

H0, there's no important relationship between leadership behavior and organizational commitment.

$\mathrm{H} 1$, there's an important relationship between leadership behavior and organizational commitment.

Hypothesis 2

H0, there's no important relationship between leadership behavior and organizational culture.

H1, there's an important relationship between leadership behavior and organizational culture.

\section{Hypothesis 3}

H0, there's no important relationship between leadership behavior and job satisfaction. $\mathrm{H} 1$, there's an important relationship between leadership behavior and job satisfaction.

\section{Research Methodology}

This research was done at a public university in Malaysia. The simplest approach to collect information directly for this study is by choosing a sample at random, particularly the chief. During this analysis, the questionnaires are employed in gathering the info connected. It's set to distribute the questionnaires to the involved respondents in person, therefore permitting us to receive reliable and correct info. Apart from that, secondary information like a journal, web supply and textbook were conjointly employed in gathering info.

Researchers already elect a hundred and fifty questionnaires to the chief at public university. The chief is the respondent for this analysis. Within the types of analysis, it might 
be ideal for checking the whole population; however, during this case, the population is too massive to incorporate each individual. This is often the explanation for selecting sampling techniques like convenience sampling, the foremost common of all techniques.

\section{Results and Analysis}

The reliability test is finished to work out whether or not the instrument employed in this study is reliable or not and to check the consistency of the queries. Cronbach's Alpha is employed to live consistency. Consistent with Zikmund (2003), if the responsibility analysis is between zero. $7-1.0$ is considered as alright, $0.6-0.7$ considers smart, $0.5-0.6$ as average and below zero.5 thought-about as poor. Supported the freelance variables on top of the responsibility datum for job satisfaction is zero.832. Meanwhile, responsibility statistics for organizational commitment are zero.853 and organizational culture is zero.993. Leadership behavior is zero.976. It shows our instrument and queries were reliable and consistent.

Table 1: Reliability test

\begin{tabular}{|c|c|}
\hline Job Satisfaction & \\
\hline Cronbach's Alpha & N of Items \\
\hline .832 & 1 \\
\hline Organization Commitment & N of Items \\
\hline Cronbach's Alpha & 11 \\
\hline .853 & N of Items \\
\hline Organizational Culture & 24 \\
\hline Cronbach's Alpha & N of Items \\
\hline .993 & 13 \\
\hline Leadership Behavior & \\
\hline Cronbach's Alpha & \\
\hline .976 & \\
\hline
\end{tabular}

\section{Summary Statistic of Respondents}

Demographic variables of the respondent sample were extracted by asking queries on age, gender, legal status, job position, range of years worked with the current leader, range of years of the firm of department and size of department (number of employees). The table below summarizes the demographic info of the sample population for this study.

Table 2: Demographic Statistics

\begin{tabular}{|c|c|}
\hline Demographic Variable & Percentage of Sample \\
\hline Age & 43.9 \\
\hline $20-29$ years & 41.4 \\
\hline $30-39$ years & 11.8 \\
\hline $40-49$ years & 3.0 \\
\hline 50 and above & 48.9 \\
\hline Gender & 51.1 \\
\hline Male & \\
\hline Female & 3.8 \\
\hline Education Level & \\
\hline Secondary & \\
\hline
\end{tabular}




\begin{tabular}{|c|c|}
\hline Diploma & 57.8 \\
\hline Postgraduate & 30.4 \\
\hline \multicolumn{2}{|l|}{ Marital Status } \\
\hline Single & 58.9 \\
\hline Married & 41.1 \\
\hline \multicolumn{2}{|l|}{ Job Position } \\
\hline Administrative or clerical & 6.4 \\
\hline Technician & 3.0 \\
\hline Executives or senior executive & 37.3 \\
\hline Assistant manager & 10.6 \\
\hline Managers or senior manager & 28.0 \\
\hline Others & 14.8 \\
\hline \multicolumn{2}{|l|}{$\begin{array}{l}\text { Number of years worked with current } \\
\text { employer }\end{array}$} \\
\hline Less than 3 years & 45.6 \\
\hline $3-6$ years & 32.9 \\
\hline $7-10$ years & 11.4 \\
\hline More than 10 years & 10.1 \\
\hline \multicolumn{2}{|l|}{ Type of organization } \\
\hline Manufacturing & 11.4 \\
\hline Service & 58.6 \\
\hline Others & 30.0 \\
\hline \multicolumn{2}{|l|}{$\begin{array}{c}\text { Number of years of establishment of the } \\
\text { organization }\end{array}$} \\
\hline Less than 10 years & 23.7 \\
\hline $10-15$ years & 17.8 \\
\hline More than 15 years & 58.5 \\
\hline \multicolumn{2}{|l|}{$\begin{array}{c}\text { Number of employees in the } \\
\text { organization }\end{array}$} \\
\hline Less than 10 & 34.5 \\
\hline $10-15$ & 23.4 \\
\hline $15-20$ & 10.6 \\
\hline More than 20 & 31.5 \\
\hline
\end{tabular}

\section{Descriptive Statistic}

The measure of organizational culture, job satisfaction and organizational culture all exhibit mean scores notably on top of their several mid-points. In distinction, the measures of leadership and organizational commitment are notably less than their mid-points. Though few inferences are gained from this analysis, however, it should be argued that demographics can be a vital issue. As associate example, drawing from past literature, the low mean several organizational commitments can be because of most respondents being young, highlyeducated and having short organizational tenures (DeCottiis and Summers, 1987; Mathieu and Hamel, 1989; Mathieu and Zajac, 1990; Michaels, 1004; Mottaz, 1988; Mowday et al., 1982; Williams and Hazer, 1986). 
Table 3: Descriptive Statistic

\begin{tabular}{|l|c|c|c|c|c|}
\hline & Valid Cases & Mean & Std. Dev & Skewness & Kurtois \\
\hline $\begin{array}{l}\text { Bureaucratic } \\
\begin{array}{l}\text { Inlture } \\
\text { Innovative }\end{array}\end{array}$ & 150 & 3.04 & 0.56 & -0.56 & 0.48 \\
$\begin{array}{l}\text { Culture } \\
\text { Supportive } \\
\text { Culture }\end{array}$ & 150 & 2.92 & 0.59 & -0.14 & 0.94 \\
\hline $\begin{array}{l}\text { Participative } \\
\begin{array}{l}\text { Leadership } \\
\text { Supportive }\end{array}\end{array}$ & 150 & 3.35 & 1.25 & 0.61 & 0.08 \\
$\begin{array}{l}\text { Leadership } \\
\begin{array}{l}\text { Directive } \\
\text { Leadership }\end{array}\end{array}$ & 150 & 3.62 & 1.19 & 0.38 & 0.17 \\
\hline $\begin{array}{l}\text { Organizational } \\
\text { Commitment }\end{array}$ & 150 & 3.31 & 1.28 & 0.25 & -0.51 \\
$\begin{array}{l}\text { Job } \\
\text { Satisfaction }\end{array}$ & 150 & 3.33 & 0.83 & -0.36 & 0.59 \\
\hline
\end{tabular}

\section{Correlation Test}

A correlation test was wont to investigate the link of the variables for the hypothesis. The man of science uses Spearman's parametric statistic to research the link between 2 or additional variables that the numerous levels are zero. 05 for every tested hypothesis. Also, the parametric statistic encompasses a vary of potential values for -1 to +1 . The worth indicates the strength of the link, whereas the sign (+ or -) indicates direction. What is more, the man of science conjointly used the Guldford Rule of Thumb because the guideline to work out the strength of the link of the variable.

Table 4: Correlation Test Leadership Behavior and Organizational Commitment

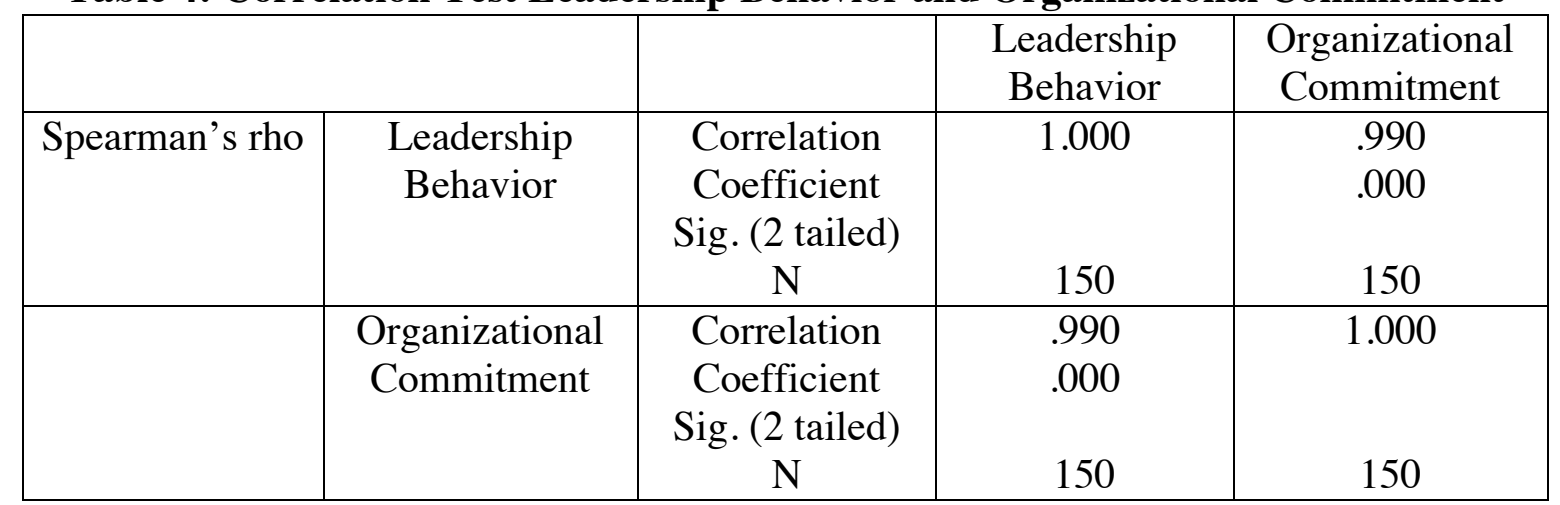

\section{Hypothesis 1}

H0 there's no important relationship between leadership behavior and organizational commitment

H1 there's no significant relationship between leadership behavior and organizational commitment 
$\mathrm{R}=.990$, Sig-value $(\mathrm{p})=.00$

Sig-value $(.000)<\mathrm{p}(0.05)$

There's a positive and extremely high relationship between leadership behavior and organizational commitment by observing the ' $r$ ' price. Since sig-value $(0.000)<p(0.005)$, therefore, the finding has, with success, rejected the null hypothesis (H0). Therefore, there's an important relationship between leadership behavior and organizational commitment.

Table 5: Correlation Test Leadership Behavior and Organizational Culture

\begin{tabular}{|l|l|l|l|l|}
\hline \multicolumn{2}{|l|}{} & & $\begin{array}{l}\text { Leadership } \\
\text { Behavior }\end{array}$ & $\begin{array}{l}\text { Organizational } \\
\text { Commitment }\end{array}$ \\
\hline Spearman's rho & $\begin{array}{l}\text { Leadership } \\
\text { Behavior }\end{array}$ & $\begin{array}{l}\text { Correlation } \\
\text { Coefficient } \\
\text { Sig. (2 tailed) } \\
\mathrm{N}\end{array}$ & 1.000 & .990 \\
& & 150 & .000 \\
\hline & $\begin{array}{l}\text { Organizational } \\
\text { Culture }\end{array}$ & $\begin{array}{l}\text { Correlation } \\
\text { Coefficient } \\
\text { Sig. (2 tailed) }\end{array}$ & .990 & 150 \\
\hline & $\mathrm{N}$ & 150 & 1.000 \\
& & & 150 \\
\hline
\end{tabular}

\section{Hypothesis 2}

H0 there's no important relationship between leadership behavior and organizational culture $\mathrm{H} 1$ there's no significant relationship between leadership behavior and organizational culture $\mathrm{R}=.990$, Sig-value $(\mathrm{p})=.00$

Sig-value $(.000)<\mathrm{p}(0.05)$

There's a positive and extremely high relationship between leadership behavior and organizational culture by observing the ' $r$ ' price. Since sig-value $(0.000)<p(0.005)$, therefore, the finding has with success, rejected the null hypothesis (H0). Therefore, there's an important relationship between leadership behavior and organizational culture.

Table 6: Correlation Test Leadership Behavior and Job Satisfaction

\begin{tabular}{|c|c|c|c|c|}
\hline \multicolumn{2}{|c|}{} & & $\begin{array}{c}\text { Leadership } \\
\text { Behavior }\end{array}$ & $\begin{array}{c}\text { Organizational } \\
\text { Commitment }\end{array}$ \\
\hline Spearman's rho & $\begin{array}{c}\text { Leadership } \\
\text { Behavior }\end{array}$ & $\begin{array}{c}\text { Correlation } \\
\text { Coefficient } \\
\text { Sig. (2 tailed) } \\
\mathrm{N}\end{array}$ & 1.000 & .991 \\
& Job Satisfaction & $\begin{array}{c}\text { Correlation } \\
\text { Coefficient } \\
\text { Sig. (2 tailed) } \\
\mathrm{N}\end{array}$ & $\begin{array}{c}.900 \\
.000\end{array}$ & 150 \\
\hline & \multicolumn{2}{|c|}{150} & 1.000 \\
\hline
\end{tabular}

\section{Hypothesis 3}

$\mathrm{H} 0$ there's no important relationship between leadership behavior and job satisfaction H1 there's no significant relationship between leadership behavior and job satisfaction $\mathrm{R}=.991$, Sig-value $(\mathrm{p})=.00$

Sig-value $(.000)<\mathrm{p}(0.05)$ 
There's a positive and extremely high relationship between leadership behavior and job satisfaction by observing the ' $r$ ' price. Since sig-value $(0.000)<p(0.005)$, therefore, the finding has with success, rejected the null hypothesis (H0). Therefore, there's an important relationship between leadership behavior and job satisfaction.

\section{Regression Analysis}

Table 5: Regression Analysis

\begin{tabular}{|c|c|c|c|c|c|}
\hline Model & \multicolumn{2}{|c|}{$\begin{array}{c}\text { Unstandardized } \\
\text { Coefficients }\end{array}$} & $\begin{array}{c}\text { Standardized } \\
\text { Coefficients }\end{array}$ & Sig. \\
\cline { 2 - 4 } & $\mathrm{B}$ & $\begin{array}{c}\text { Std. } \\
\text { Error }\end{array}$ & Beta & & \\
\hline 1 (Constant) & .872 & .153 & .003 & 5.689 & .000 \\
$\begin{array}{c}\text { Organizational } \\
\text { Commitment }\end{array}$ & -.002 & .116 & .018 & .986 \\
$\begin{array}{c}\text { Organizational } \\
\text { Culture }\end{array}$ & .380 & .099 & .499 & 3.332 & .001 \\
Job Satisfaction & .384 & .115 & .500 & 3.819 & .000 \\
\hline
\end{tabular}

The regression analysis shows an issue that almost all affected from the leadership behavior. From the regression analysis, among the factors that almost all affected from leadership behavior is that the job satisfaction (.500) so follow by organization culture (4.99) and in conclusion organizational commitment (-.003).

\section{Conclusions}

In starting, all hypothesizers concerning this study were proved to be right. There's a big relationship between leadership behavior and organizational commitment, there's a big relationship between leadership behavior and organizational culture, and there is a significant relationship between leadership behavior and job satisfaction. Yousef (2000) expressed that worker is extremely committed to the organization with the proper leadership behaviour.

During this study, though the correlations were statistically important ( $\mathrm{p}<$ zero.05), the number of correlations with every variable was comparatively tiny. One amongst the explanations can be that there is an alternative, probably stronger, predictors and dependents for the variables investigated during this study. As an example, there are varied factors that influence or are influenced by job satisfaction, as represented by Rad and Yarmohammadian (2006).

For future researchers, sampling was one of the restrictions known during this study. The fact that convenience sampling was used meant that results weren't directly transferable to the final operating population. Additionally, the sample subjects during this study were largely executives within the public university at Malaya. Thus, the finding couldn't be generalized. Therefore, the future analysis may investigate extending the study population to incorporate collect input from gone through business manager and leaders WHO have a higher insight of the operating of the corporation. The number of respondents conjointly ought to be increasing to urge additional valid answers. Consecutive man of science ought to get a bigger range of respondents to represent the whole population. Apart from that, a 
consecutive man of science may give ass additional dependent variables and mediator variables.

\section{References}

Allen, D. (2003). Organisational Climate and Strategic Change in Higher Education: Organisational Insecurity. Higher Education, 46(1), 61-92.

Allen, N. And Meyer, J. (1990). The Measure and Antecedents of Emotional, Normative and Continuance Commitment to the Organization. Journal of Activity Psychological Science, 63, 1-18.

Amos, E., A. \& Weathington, B., L. (2008). Associate Analysis of The Relation Between Worker-Organization Price Harmony and Employee Attitudes. Journal of Psychological Science, 142 (6), 615-631.

Beer, M. \& Nohria, N. (2000). Cracking the Code of Change. Harvard Business Review. May-June 2000, 133-141

Bodla, M., \& Nawaz, M. (2010). Transformational Leadership Vogue and Its Relationship with Satisfaction. Knowledge Base Journal of Latest Analysis in Business, 12, 370381.

Bratton, J., Grint, K., \& Nelson, D. (2005), Organizational Leadership. Thomson SouthWestern. Mason, $\mathrm{OH}$.

Burns, J. M. (1978), Leadership. Harper and Row. New York.

Carter, L., Ulrich, D., \& Goldsmith, M. (2005), Best Practices in Leadership Development and Organization Amendment: How the Best Companies Ensure Meaningful Change and Sustainable Leadership. Pfeifer. San Francisco

Barroso Castro, C., Villegas Perinan, M.M., \& Casillas Bueno, J.C. (2008). Transformational leadership and follower's attitudes: The mediating role of psychological empowerment. International Journal of Human Resource Management, 19, 1842-1863.

Daft, R., L. (2005), The Leadership Expertise. 3rd Ed. Thomson South-Western. Canada.

Dunham, R. B., Grube, J. A., \& Castaneda, M. B. (1994). Organizational commitment: The utility of an integrative definition. Journal of Applied Psychology, 79, 370-380.

Grant, T. (1996), International Directory of Company Histories Vol. 12. St. James Press. New York.

Grant, R. M. (1996). Toward A Knowledge-Based Theory of the Firm. Strategic Management Journal, 17, Special Issue: Knowledge and the Firm, 109-122.

Kavanagh, M. H. \& Ashkanasy, N. M. (2006). The Impact of Leadership and Change Management Strategy on Organisational Culture and Individual Acceptance of Change during A Merger. British Journal of Management, 12, 81-103.

Kotter, J. P. (2008). What leaders really do. Business Leadership: A Jossey-Bass reader, 2nd Edition, 5-15.

Limsila, K. \& Ogunlana, S.O. (2008). Performance and Leadership Outcome Correlates of Leadership Style And Subordinate Commitment. Engineering, Construction and Architectural Management, 15, 164-184.

Maqsood, S., Bilal, H., Nazir, S., \& Baig, R. (2013). Manager's Leadership styles and Employee's Job Satisfaction. Human and Social Science Research. 1(2).

Mohammad, J., Habib, F., \& Alias, M. (2011). Job Satisfaction and Organisational Citizenship Behavior: An Empirical Study at Higher Learning Institutions. Asian Academy of Management Journal, 16(2), 149-165. 
Okpara, J.O. (2004), "Job Satisfaction and Organisational Commitment: Are There Differences between American and Nigerian Managers Employed in the US MNCs in Nigeria?", in The Academy of Business and Administrative Sciences (ABAS) International Conference, Montreux, June 2004, 12-14.

Porter, L. W., Steers, R. M., Mowday, R. T., \& Boulian, P. V. (1974). Organizational commitment, job satisfaction, and turnover among psychiatric technicians. Journal of Applied Psychology, 59(5), 603-609.

Raju, P. M., \& Srivastava, R. C. (1994). Factors Contributory to Commitment to the Teaching Profession. International Journal of Education Management, 8(5), 7-13.

Robbins, S. P. (2003). Organisational Behavior (10" ed). Prentice Hall. San Diego.

Shamir, B., Zakay, E., Breinin, E., B., \& Popper, M. (1998). Correlates of Charismatic Leader Behavior in Military Units: Subordinates' Attitudes, Unit Characteristics, and Superiors' Appraisals of Leader Performance. Academy of Management Journal, 41(4), 387-409.

Shastri, R. K., Shashi, M. K., \& Sinha, A. (2010). Charismatic leadership and organizational commitment: An Indian perspective. African Journal of Business Management, 4(10), 1946-1953.

Sheehan, C. R., Cooper, B., Holland, P. J., \& De Cieri, H. L. (2007). The relationship between HRM avenues of political influence and perceived organizational performance. Human Resource Management, 46(4), 611 - 629.

Tale, S. M. (2010). Leadership Style and Job Satisfaction among Nurses. Master of Human Resource Management University Utara Malaysia.

Oreg, S., \& Berson, Y. (2011). Leadership and Employees' Reactions to Change: The Role of Leaders' Personal Attributes and Transformational Leadership Style.

Wallach, E. (1983). Individuals and Organization: The Cultural Match. Training and Development Journal, 12, 28-36.

Williams, L. J., \& Anderson, S. E. (1991). Job Satisfaction and Organisational Commitment as Predictors of Organisational Citizenship and In-Role Behaviors. Journal of Management, 17, 601-617.

Yiing, L. H. (2008). The Association Between Organisational Culture and Leadership Behaviour and Organisational Commitment, Job Satisfaction and Employee Performance - A Malaysian Perspective. Faculty of Business and Accountancy University of Malaya.

Yousef, D., A. (2000). Organisational Commitment: A Mediator of the Relationships of Leadership Behavior with Job Satisfaction and Performance in a Non-Western Country. Journal of Managerial Psychology, 15, 6-24. 